\title{
Sustained activation of C3aR in a human podocyte line impairs the morphological maturation of the cells
}

\author{
JING-MIN ZHENG, SHA-SHA WANG, XIONG TIAN and DE-JUN CHEN \\ Department of Nephrology, Taizhou Hospital, Wenzhou Medical University, Linhai, Zhejiang 317000, P.R. China
}

Received March 30, 2020; Accepted September 2, 2020

DOI: $10.3892 / \mathrm{mmr} .2020 .11626$

\begin{abstract}
The $\mathrm{C} 3 \mathrm{a}$ receptor $(\mathrm{C} 3 \mathrm{aR})$ has been reported to be involved in various physiological and pathological processes, including the regulation of cellular structure development. Expression of $\mathrm{C} 3 \mathrm{aR}$ has been reported in podocytes; however, data concerning the role of $\mathrm{C} 3 \mathrm{aR}$ in podocyte morphology is scarce. The aim of the present study was to examine the effect of C3aR activation on the architectural development of podocytes. An immortal human podocyte line (HPC) was transfected with a C3a expression lentivirus vector or recombinant C3a. SB290157 was used to block the activation of C3aR. The expression of $\mathrm{C} 3 \mathrm{a}$ in HPC cells was analyzed by reverse transcription-quantitative PCR (RT-qPCR) and ELISAs. Phase contrast and fluorescence microscopy were used to observe the morphology of the podocytes. The adhesive ability of HPC cells was analyzed using an attachment assay. RT-qPCR, cyto-immunofluorescence and western blotting were used to determine the expression levels of the adhesion-associated genes. The expression levels of carboxypeptidases in HPC cells was also detected by RT-qPCR. Compared with the untransfected and control virus-transfected HPC cells, the $\mathrm{C} 3 \mathrm{a}$-overexpressing cells (HPC-C3a) failed to expand their cell bodies and develop an arborized appearance in the process of maturation, which the control cells exhibited. In addition, HPC-C3a cells presented with decreased adhesive capacity, altered focal adhesion (FA) plaques and decreased expression of FA-associated genes. These effects were blocked by a $\mathrm{C} 3 \mathrm{aR}$ antagonist; however, the addition of purified $\mathrm{C} 3 \mathrm{a}$ could not completely mimic the effects of $\mathrm{C} 3 \mathrm{a}$ overexpression. Furthermore, HPC cells expressed carboxypeptidases, which have been reported to be able to inactivate C3a. In summary, the results demonstrated that sustained $\mathrm{C} 3 \mathrm{aR}$ activation impaired the morphological maturation of HPC cells, which may be associated with the altered expression of FA-associated
\end{abstract}

Correspondence to: Professor Jing-Min Zheng, Department of Nephrology, Taizhou Hospital, Wenzhou Medical University, 150 Ximenjie Street, Linhai, Zhejiang 317000, P.R. China

E-mail: zhengjingmin@enzemed.com

Key words: human $\mathrm{C} 3 \mathrm{~A}$ anaphylatoxin receptor, complement, podocyte, morphological maturation genes and impaired FA. Since chronic complement activation has been reported in renal diseases, which indicate sustained $\mathrm{C} 3 \mathrm{aR}$ activation in renal cells, including podocytes and podocyte progenitors, the possible role of $\mathrm{C} 3 \mathrm{aR}$ in the dysregulation of podocyte architecture and podocyte regeneration requires further research.

\section{Introduction}

As a part of the immune system, the complement system is initially involved in host defense against pathogens. Notably, recent research has indicated that the complement system may also have certain non-immune functions and serve roles in physiological and pathological processes $(1,2)$; for example, the complement system was discovered to be involved in the control of tissue morphogenesis, wound healing and synaptic pruning (1).

Human C3a anaphylatoxin (C3a), a C3 split fragment produced during the activation of the complement system, is one of the complement molecules that have been reported to serve non-immune roles. C3a was initially reported to be involved in the chemotaxis, recruitment and activation of inflammatory cells by binding to the $\mathrm{C} 3 \mathrm{a}$ receptor $(\mathrm{C} 3 \mathrm{aR})$ on immune cells (3-5). However, C3aR has also been demonstrated to be expressed by certain non-immune cells, including in liver, kidney and nerve cells. Additionally, C3aR signaling has been revealed to participate in various physiological and pathological processes, including in the regulation of metabolism $(6,7)$, histogenesis $(8,9)$ and tissue repair (10). In the nervous system, C3aR was reported to be expressed by gliocytes, neural stem cells, neural progenitors and mature neurons (11-13), and was found to be involved in the regulation of neurogenesis and neural regeneration (14). Notably, C3aR signaling was demonstrated to be directly associated with the structure of neural development processes. Furthermore, $\mathrm{C} 3 \mathrm{aR}$ has been implicated in axonal sprouting, neurite extension, synapsis formation and the recovery of injured neural structure and function $(14,15)$.

Podocytes exhibit an octopus-like dendritic morphology consisting of a cell body, major processes and foot processes, similar to neural cells. Foot processes from neighboring podocytes interdigitate with each other, cover the outer side of the glomerular basement membrane and constitute one of the most important components of the glomerular filtration barrier. This unique architecture is the basis for podocyte 
function (16). Damage to podocyte structure, including foot process effacement, which is the retraction and flattening of foot processes, was confirmed to be directly associated with proteinuria in kidney diseases and the recovery of podocyte structure lead to remission $(17,18)$. Despite the importance of the cellular structure in podocyte function, the mechanism underlying the management and regulation of podocyte architecture remains unclear.

$\mathrm{C} 3 \mathrm{aR}$ expression in glomerular podocytes has been reported by several studies $(19,20)$. However, data concerning the role of $\mathrm{C} 3 \mathrm{aR}$ in podocytes is limited. Considering the morphological similarity between nerve cells and podocytes, and the role of $\mathrm{C} 3 \mathrm{aR}$ in the neurogenesis, particularly in the regulation of neural morphology, we hypothesized that $\mathrm{C} 3 \mathrm{aR}$ may serve a role in the development and management of podocyte architecture.

Derived from primarily cultured human glomerular podocytes, the conditionally immortal human podocyte line (HPC) mimics the process of podocyte architecture development. During the proliferation condition, the cells exhibit a typical cobblestone morphology. In the maturation condition, the cells undergo proliferation arrest, enlargement of the cell bodies and the development of the arborized form, with the formation of processes and a slit diaphragm complex, and the expression of podocyte-specific markers (21).

To investigate the possible role of C3aR signaling in the regulation of podocyte architecture development, the current study examined the effect of C3aR activation on the development of podocyte morphology by the overexpression of $\mathrm{C} 3 \mathrm{a}$ in HPC cells and discussed the underlying molecular mechanism.

\section{Materials and methods}

Cell culture and stable overexpression of C3ain HPC cells.HPC was provided by Professor M.A. Saleem (Children's Renal Unit and Academic Renal Unit, University of Bristol) and cultured as previously described (21). Briefly, the cells were cultured in RPMI-1640 medium (Dalian Meilun Biology Technology Co., Ltd.) supplemented with 10\% FBS (Gibco; Thermo Fisher Scientific, Inc.) and 1X Insulin-Transferrin-Selenium (Gibco; Thermo Fisher Scientific, Inc.) at $33^{\circ} \mathrm{C}$ for propagation (the proliferation condition) and at $37^{\circ} \mathrm{C}$ for differentiation (the maturation condition).

To obtain HPC cells stably overexpressing secretory $\mathrm{C} 3 \mathrm{a}$, the cells cultured in the proliferation condition were transfected with a recombinant lentivirus Lenti-C3a. The lentivirus was constructed based on a previous study (22), in which mouse secretory C3a was expressed by inserting the IL-6 signal peptide sequence prior to the C3a coding sequence. Similarly, a recombinant human C3a gene IL6 C3a containing the IL-6 signal peptide sequence (117-203 of NM_000600.3) and C3a coding sequence (2076-2306 of NM_000064.2) was synthesized. Following this, the expression vector pLenti6.3-IL6C3a-IRES2-EGFP was constructed by inserting the IL6C3a gene into the BamHI/AscI site of the pLenti6.3-MCS-IRES2-EGFP vector (Invitrogen; Thermo Fisher Scientific, Inc.). Finally, lentivirus Lenti-C3a was produced in $293 \mathrm{~T}$ cells using the expression vector pLenti6.3-IL6C3a-IRES2-EGFP. Infection of HPC cells was performed when the cells cultured in the proliferation condition reached $\sim 50 \%$ confluence.
At 2 days post-infection, the transfected cells were examined under a fluorescence microscope and $>80 \%$ of the cells were found to have been transfected successfully. The cells were transferred to the selection medium containing $10 \mu \mathrm{g} / \mathrm{ml}$ blasticidin. Two weeks later, stably transfected HPC cells (HPC-C3a) were obtained. Vector pLenti6.3-MCS-IRES2-EGFP was directly used to construct the negative control (NC) lentivirus (Lenti-NC). Infection with Lenti-NC produced the HPC-NC cells. HPC-C3a cells cultured in medium containing $1 \mu \mathrm{M}$ SB290157 (Merck KGaA) were used as the C3aR blocking control.

In the $\mathrm{C} 3 \mathrm{a}$ stimulation tests, purified human $\mathrm{C} 3 \mathrm{a}$ (Merck KGaA) was directly added to the cell culture medium once every two days at $37^{\circ} \mathrm{C}$ for a total of 6 days at a final concentration of $100 \mathrm{nM}$.

Cell morphology observation. To examine the morphological changes in the process of maturation, HPC cells (including untransfected HPC, HPC-NC, HPC-C3a and SB290157-treated HPC-C3a cells) were examined under phase contrast (Leica Microsystems $\mathrm{GmbH}$; magnification, x200) and fluorescence microscopes (Zeiss $\mathrm{GmbH}$; magnification, $\mathrm{x} 400$ ) following $0,2,7$ and 14 days of being in the maturation condition. Given that normal HPC cells do not exhibit fluorescence, only the morphology of HPC-NC, HPC-C3a and HPC-C3a cells treated with SB290157 were visualized using fluorescence microscopy.

Cell adhesion assay. Cell adhesion assays were performed in rat tail collagen I-coated 24-well plates. Following treatment with various conditions, the cells (HPC, HPC-NC and HPC-C3a) were detached using Accutase solution (Sigma-Aldrich; Merck KGaA) and $2 \times 10^{5}$ cells were allowed to attach to the collagen I-coated plates in $0.5 \mathrm{ml}$ RPMI-1640 medium supplemented with $0.1 \%$ FBS. Time course adhesion assays were performed at time points $30 \mathrm{~min}, 1 \mathrm{~h}$ and $3 \mathrm{~h}$ at $37^{\circ} \mathrm{C}$ in a $5 \% \mathrm{CO}_{2}$ incubator. Following this, the non-adherent cells were collected, and the adherent cells were detached with Accutase solution. The numbers of both adherent and non-adherent cells were counted using a cell counter. The cell adhesion ability was represented by the ratio of adherent cells to non-adherent cells and was further calibrated to that of non-treated HPC cells (the adhesion ability of non-treated HPC cells was defined as 1.0). To compare the adhesive ability between HPC, HPC-NC, HPC-C3a and SB290157-treated HPC-C3a cells, the cells were cultured in the maturation condition for 6 days before the assay began.

$R N A$ isolation and reverse transcription-quantitative PCR $(R T-q P C R)$. TRIzol ${ }^{\circledR}$ reagent (Invitrogen; Thermo Fisher Scientific, Inc.) was used to extract total RNA from the cultured HPC, HPC-NC or HPC-C3a cells. cDNA was generated using a PrimeScriptTM RT Master Mix kit (Takara Biotechnology Co., Ltd.), according to the manufacturer's protocol, and analyzed by RT-qPCR using $1 \mu \mathrm{l}$ of cDNA, $250 \mathrm{nM}$ primers and UltraSYBR mixture (CoWin Biosciences). 18S RNA was used as the endogenous control. The sequences of the primers are presented in Table I. The following thermocycling conditions were used to detect the expression levels of nephrin: Initial denaturation at $95^{\circ} \mathrm{C}$ for $5 \mathrm{~min}$; followed by 40 cycles of $95^{\circ} \mathrm{C}$ for $20 \mathrm{sec}, 58^{\circ} \mathrm{C}$ for $10 \mathrm{sec}$ and $72^{\circ} \mathrm{C}$ for $45 \mathrm{sec}$; and a final extension 
Table I. Primers used for reverse transcription-PCR.

\begin{tabular}{|c|c|c|}
\hline Gene & Forward sequence $\left(5^{\prime}-3^{\prime}\right)$ & Reverse sequence $\left(5^{\prime}-3^{\prime}\right)$ \\
\hline COL1A1 & atcaaccggaggaatttccgt & caccaggacgaccaggttttc \\
\hline COL4A1 & cggatcacattgacatgaaacc & accagtccatgctcgcaaag \\
\hline COL4A2 & tggacctgatggaaagcgag & tgctcctttcagcccaaaca \\
\hline COL4A3 & ggtggcctgagagcctga & tcacagaagcactggccttt \\
\hline COL4A4 & ccagcccgcetccaac & gtgaggttctgtgttctgggt \\
\hline FN1 & gagaataagctgtaccatcgcaa & cgaccacataggaagtcccag \\
\hline LAMA1 & ttagccaccgggaacctaaag & gccatagcagatacacatgcct \\
\hline LAMB1 & tgactttcaagacattccgtcc & aggcgaagtatctatacacaccc \\
\hline LAMC1 & actgccactgacatcagagta & gcttgcgtgtccattacatttac \\
\hline LAMA2 & gccaacgctgagaaacttgag & gagctccacaaaaccaggct \\
\hline LAMB2 & agcaatgggcagagttggaa & ggctcaaggcagacaggatt \\
\hline LAMC2 & ggagctggagtttgacacgaa & agcttctgctccagtaagacc \\
\hline LAMA3 & gggtgctgctcaaagcaaag & gctgcagtacagaggcttca \\
\hline LAMB3 & cagtcacagagcaggaggtg & tctccaggtctctcggaagg \\
\hline LAMC3 & tacggcaaacagaaccctc & gatcagccagcagagtcctg \\
\hline ITGA1 & gtgcttattggttctccgttagt & cacaagccagaaatcctccat \\
\hline ITGA2 & tccagagtaacctccagggg & gccagggttttccagactga \\
\hline ITGA3 & cccagaggaccaaggaaacc & attgttcaggtctgccaggg \\
\hline ITGA5 & ggagaggagcctgtggagta & cctccttggcagtaaccetg \\
\hline ITGB1 & gtaaccaaccgtagcaaagga & tcccctgatcttaatcgcaaaac \\
\hline ITGB3 & gaagcagagtgtgtcacgga & acatgacactgcccgtcatt \\
\hline DAG1 & ggaaggaggctttgccatct & gaacacactggaggtctggg \\
\hline PTK2 & catgccctcaaccagggatt & cacgctgtccgaagtacagt \\
\hline ILK & gcagcccgagtcccgaggata & gcgecgagtcccetggattg \\
\hline NRP1 & gcggacttttccagctctct & cagttggcetggtcgtcat \\
\hline TLN1 & agaacggaaacctgccagag & tgaattgcctggtttgcacg \\
\hline TLN2 & tgacctaaattggctggatcac & aacttccgtctaagcagcaac \\
\hline PXN & catggacgacctcgacgc & gaggctgctggtggatgaat \\
\hline FERMT2 & gatgctgccetttcagacct & ctggtgtgccactggattct \\
\hline VCL & cgtccgggttggaaaagaga & gacctcagcctcatcgaagg \\
\hline ACTA2 & gggactaagacgggaatcct & gtcacccacgtagctgtctt \\
\hline WT1 & cccattgccatttggtgtgg & ccgatgcettgetctctgat \\
\hline TGFB1 & atggagagaggactgcggat & tagtgttccccactggtccc \\
\hline 18S RNA & tttctcgattccgtgggtgg & agcatgccagagtctcgttc \\
\hline $\mathrm{C} 3 \mathrm{aR}$ & tgaagccttcagctactgtctcag & ggacaatgatggaggggatgag \\
\hline $\mathrm{C} 3 \mathrm{a}$ & aagtcggcaagtaccccaag & agttgcagcagtccaggaag \\
\hline CPD & cccgaccagtttagcaccg & actgagccaccatgcagattt \\
\hline CPM & tgtgggttcttgttgtgggg & agggtctttgccatcactgg \\
\hline CPN1 & ggtgattacttccggctgct & cactttggctctgactccgt \\
\hline CPN2 & acaccagactcctctctgct & gagcagaacacctcctggac \\
\hline $\mathrm{CPZ}$ & getccttacagtcetggtcg & aagtgctctgacagtgtggg \\
\hline Nephrin & tggcgattcctgcetccgtt & ttctgctgggagccctcgtt \\
\hline
\end{tabular}

COL1A1, collagen I $\alpha 1$; COL4A1, collagen IV $\alpha 1$; COL4A2, collagen IV $\alpha 2$; COL4A3, collagen IV $\alpha 3$; COL4A4, collagen IV $\alpha 4$; C3aR, complement C3a receptor 1; FN1, fibronectin-1; LAMA1, laminin $1 \alpha$; LAMB1, laminin 1 $\beta$; LAMC1, laminin 1 $\gamma$; LAMA1, laminin $\alpha 1$; LAMB2; laminin $\beta 2$; LAMC2, laminin $\gamma 2$; LAMA3, laminin $\alpha 3$; LAMB3, laminin $\beta 3$; LAMC3, laminin $\gamma 3$; ITGA1, integrin $\alpha 1$; ITGA2, integrin $\alpha 2$; ITGA3, integrin $\alpha 3$; ITGA5, integrin $\alpha 5$; ITGB1, integrin $\beta 1$; ITGB3, integrin $\beta 3$; DAG1, dystroglycan 1 ; PTK2, protein tyrosine kinase 2; ILK, integrin linked kinase; NRP1, neuropilin 1; TLN1, talin 1; TLN2, talin 2; PXN , paxillin; FERMT2, fermitin family member 2; VCL, vinculin; ACTA2, $\alpha$ smooth muscle actin; WT1, Wilms' tumor 1; TGFB1, transforming growth factor $\beta 1$; CPD, carboxypeptidase D; CPM, carboxypeptidase M; CPN1, carboxypeptidase N1; CPN2, carboxypeptidase N2; CPZ, carboxypeptidase Z.

at $72^{\circ} \mathrm{C}$ for $5 \mathrm{~min}$. The following thermocycling conditions were used for the rest of the genes: Initial denaturation at $95^{\circ} \mathrm{C}$ for
$5 \mathrm{~min}$; followed by 40 cycles of $95^{\circ} \mathrm{C}$ for $20 \mathrm{sec}, 60^{\circ} \mathrm{C}$ for $20 \mathrm{sec}$ and $72^{\circ} \mathrm{C}$ for $30 \mathrm{sec}$; and a final extension at $72^{\circ} \mathrm{C}$ for $5 \mathrm{~min}$. The 
expression levels were quantified using the $2^{-\Delta \Delta \mathrm{Cq}}$ method (23) and finally normalized to the expression levels of in the HPC control cells (which was set to 1.0).

Western blotting. Total protein was extracted from the cultured HPC, HPC-NC or HPC-C3a cells using RIPA lysis buffer (Beyotime Institute of Biotechnology) containing a Protease Inhibitor Cocktail (Roche Diagnostics) at $4^{\circ} \mathrm{C}$. Total protein was quantified using a BCA Protein Assay kit (Beyotime Institute of Biotechnology) and $10 \mu \mathrm{g}$ protein/lane was separated via $8 \%$ SDS-PAGE, then transferred to a PVDF membrane (Merck KGaA). Following blocking with 5\% skim milk powder at room temperature for $4 \mathrm{~h}$, the membrane was probed with primary antibodies, including rabbit anti-human C3aR polyclonal (cat. no. sc-20138; Santa Cruz Biotechnology, Inc.; dilution 1:1,000), rabbit anti-human integrin $\beta 1$ polyclonal (ITGB1; cat. no. 9699S; Cell Signaling Technology, Inc.; dilution 1:1,500), rabbit anti-human vinculin (VCL; cat. no. 26520-1-AP; ProteinTech Group, Inc.; dilution 1:1,000), rabbit anti-human protein tyrosine kinase 2 (PTK2; cat. no. 71433; Cell Signaling Technology, Inc.; dilution 1:1,000) or mouse anti-human GAPDH monoclonal (cat. no. MB001; Bioworld Technology, Inc; dilution 1:10,000) antibodies at $4^{\circ} \mathrm{C}$ overnight. The membranes were then incubated with horseradish peroxidase (HRP)-conjugated secondary goat anti-rabbit IgG (cat. no. HS101-01; TransGen Biotech Co., Ltd; dilution 1:2,000) or goat anti-mouse IgG (cat. no. BS12478; Bioworld Technology, Inc.; dilution 1:10,000) antibodies for $1 \mathrm{~h}$ at room temperature. The immunolabeled proteins were detected by chemiluminescence using the Chemiluminescent HRP substrate (Merck KGaA). Densitometric analysis was performed using ImageJ version 1.52a software (National Institutes of Health).

Cyto-immunofluorescence. The HPC, HPC-NC or HPC-C3a cells growing on glass coverslips were washed with $\mathrm{PBS}$, fixed in $4 \%$ paraformaldehyde at $4^{\circ} \mathrm{C}$ for $30 \mathrm{~min}$ and permeabilized in $0.5 \%$ Triton $\mathrm{X}-100$ at room temperature for $10 \mathrm{~min}$. Following blocking with 3\% BSA (Beyotime Institute of Biotechnology) for $30 \mathrm{~min}$, the cells were incubated with rabbit anti-human C3aR (dilution 1:50) or rabbit anti-human VCL (dilution 1:100) antibodies at room temperature for $2 \mathrm{~h}$. After washing with PBS three times, the cells were incubated with Cy3-labled goat anti-rabbit IgG antibodies (cat. no. 33108ES60; Shanghai Yeasen Biotechnology Co., Ltd.; dilution 1:200) at room temperature for $30 \mathrm{~min}$. The cells were washed again with PBS and exposed to DAPI solution (Beyotime Institute of Biotechnology) at room temperature for $5 \mathrm{~min}$. Following washing with PBS, the cells were mounted, and fluorescent images were captured with a confocal microscope (LSM-800; Zeiss $\mathrm{GmbH}$; magnification, x400). Homologous serum was used instead of the primary antibody for the control.

Measurement of C3a levels. C3a levels was measured using a human C3a ELISA kit (BD Biosciences), according to the manufacturer's protocol.

Statistical analyses. Data are presented as the mean \pm SEM. SPSS software (version no. 19.0; SPSS, Inc.) was used for data analysis. Multiple comparisons were performed using one-way ANOVA and Tukey's post hoc test was used in the comparison between two groups. All statistical tests were two-tailed. $\mathrm{P}<0.05$ was considered to indicate a statistically significant difference.

\section{Results}

C3aR is expressed by HPC cells. To investigate the effect of $\mathrm{C} 3 \mathrm{aR}$ activation in HPC cells, the expression of $\mathrm{C} 3 \mathrm{aR}$ was examined. The results of RT-qPCR, western blotting and immunofluorescence demonstrated that $\mathrm{C} 3 \mathrm{aR}$ was expressed by HPC cells (Fig. 1). The expression of C3aR was observed on the cell surface and in the cytoplasm.

Secretory C3a is overexpressed in HPC-C3a cells. To determine whether $\mathrm{C} 3 \mathrm{a}$ is overexpressed by HPC-C3a cells, C3a mRNA and protein levels were measured by RT-qPCR and ELISA, respectively. RT-qPCR results demonstrated that the expression levels of C3a mRNA was significantly increased in the HPC-C3a cells compared with HPC-NC and untransfected HPC cells ( $768.18 \pm 116.11$ vs. $1.17 \pm 0.16$ and $1.00 \pm 0.02$, respectively; Fig. 2A). Furthermore, the ELISA analysis reported that the expression of $\mathrm{C} 3 \mathrm{a}$ protein was significantly increased in the cultured medium of HPC-C3a cells compared with the HPC-NC and untransfected HPC cells $(563.63 \pm 69.86$ vs. $0.34 \pm 0.06$ and $0.37 \pm 0.11 \mathrm{ng} / \mathrm{ml}$, respectively; Fig. 2B).

Influence of overexpression of C3a in the phenotype of HPC cells during their maturation. As shown in Fig. 3A, at the proliferation condition, HPC cells grew with typical cobblestone morphology. Shifting the cells to the maturation condition resulted in the arrest of cell proliferation and differentiation. The cell bodies enlarged in a time-dependent manner and various cellular projections developed. Within two weeks, the cells converted from individual cobblestone morphology into an arborized appearance, which resembled the morphology of mature glomerular podocytes in vivo (21). Similar to the untransfected HPC cells, HPC-NC cells exhibited typical cobblestone morphology in the proliferation condition and ceased proliferation in the maturation condition. Additionally, HPC-NC cells became enlarged and developed arborized morphology within two weeks. No obvious morphological change was observed in HPC-C3a cells cultured in the proliferation condition. However, these cells failed to undergo cell body expansion, which the HPC-NC and untransfected HPC cells underwent in the maturation condition. HPC-C3a cells cultured in the maturation condition appeared to exhibit decreased adhesive capacity and became extremely sensitive to the regular change of the medium. Increased contracted cells, which could be easily detached from the surface of the culture plate with gentle shaking, were observed in the HPC-C3a group starting on the 5th day following transference to the maturation condition and the regular change of medium would induce contraction of the cells immediately (within $<30 \mathrm{~min}$ ). The cell numbers of HPC-C3a decreased markedly since about the 6th day. Within 2 weeks, most of the HPC-C3a cells were lost and the cells still remained in culture plate failed to develop into the arborized appearance as the untreated HPC and HPC-NC cells did. Addition of SB290157 (SB) blocked the phenotypic alterations caused by Lenti-C3a infection. The morphological differences in the formation of the arborized morphology, which was observed in HPC-NC and SB290157-treated HPC-C3a cells, 
A

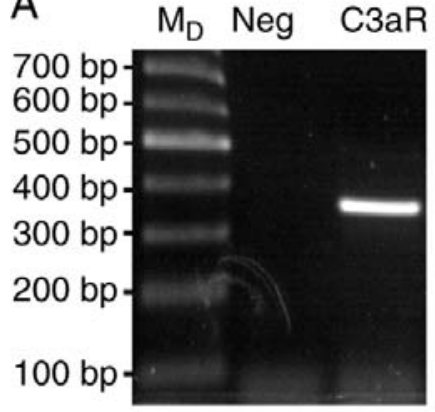

C C3aR staining

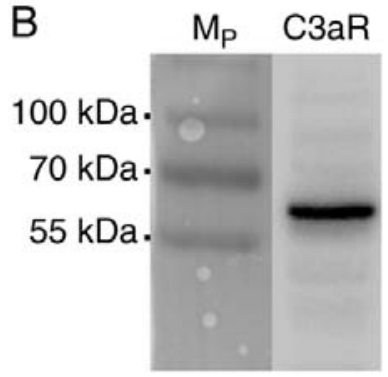

Negative control
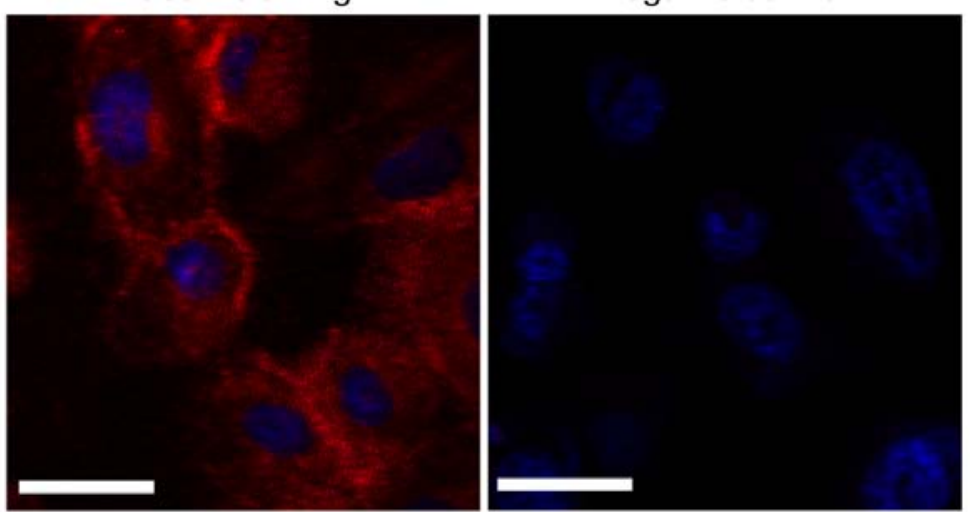

Figure 1. Results of RT-qPCR, western blotting and immunofluorescence demonstrated that C3aR is expressed by HPC cells. Results for (A) RT-qPCR, (B) western blotting and (C) immunofluorescence staining for C3aR. Scale bar, $50 \mu \mathrm{M}$. Homologous serum was used instead of anti-C3aR antibody as the negative control in (C). RT-qPCR, reverse transcription-quantitative PCR; C3aR, human C3a anaphylatoxin receptor; HPC, human podocyte cell line; Md, DNA molecular weight; Neg, negative control; Mp protein molecular weight.
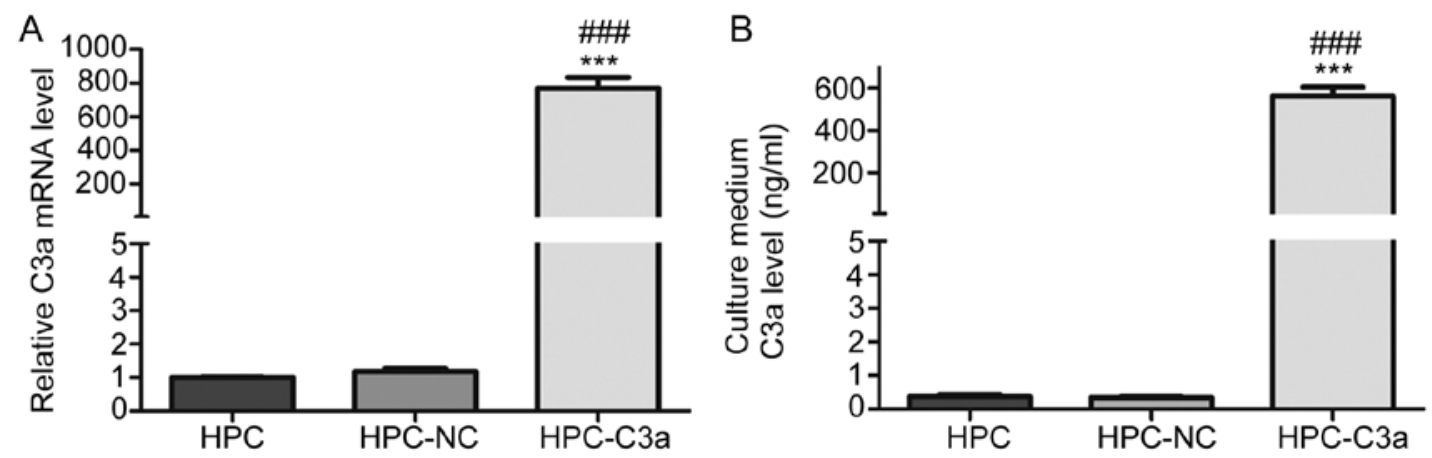

Figure 2. C3a was proved to be overexpressed in HPC-C3a cells compared with HPC-NC and untransfected HPC cells. The overexpression of C3a in HPC-C3a cells was confirmed at the (A) mRNA level by reverse transcription-PCR and the (B) protein level by measuring C3a in the cultured medium using an ELISA kit. ${ }^{* * *} \mathrm{P}<0.001$ vs. the HPC group; ${ }^{\# \#} \mathrm{P}<0.001$ vs. the HPC-NC group. C3a, human C3A anaphylatoxin; HPC, human podocyte cell line; NC, negative control.

but not in HPC-C3a cells, were more clearly pronounced under the fluorescence microscope since HPC-NC and HPC-C3a cells have fluorescence due to the expression of EGFP (Fig. 3B). However, as the untransfected HPC cells have no fluorescence, these cells were not observed under the fluorescence microscope. Furthermore, HPC-C3a cells exhibited decreased adhesion capacities compared with the $\mathrm{C} 3 \mathrm{a}$ group, as confirmed by the adhesion assays (Fig. 3C).

Effect of C3a overexpression on the structure of focal adhesion (FA). FAs are macromolecular complexes located at the sites of cell adhesion to extracellular matrices (ECMs) and serve a key role in cell adhesion to the ECM (24). To determine whether the decreased adhesion capacity of HPC-C3a cells is associated with the alteration of FAs, the cells were stained with antibodies against VCL, a core component of FAs. Different immunostaining patterns for VCL were observed in the HPC-C3a cells compared with the untransfected HPC and HPC-NC cells (Fig. 4). Immunostaining was observed mainly in the center of HPC-C3a cells and fewer and smaller VCL-positive plaques were observed in the peripheral area of the cells. SB290157 treatment (SB) blocked the VCL-induced alterations in the HPC-C3a cells.

Effect of C3a overexpression on the expression of cell adhesion-associated genes. To explore the underlying 

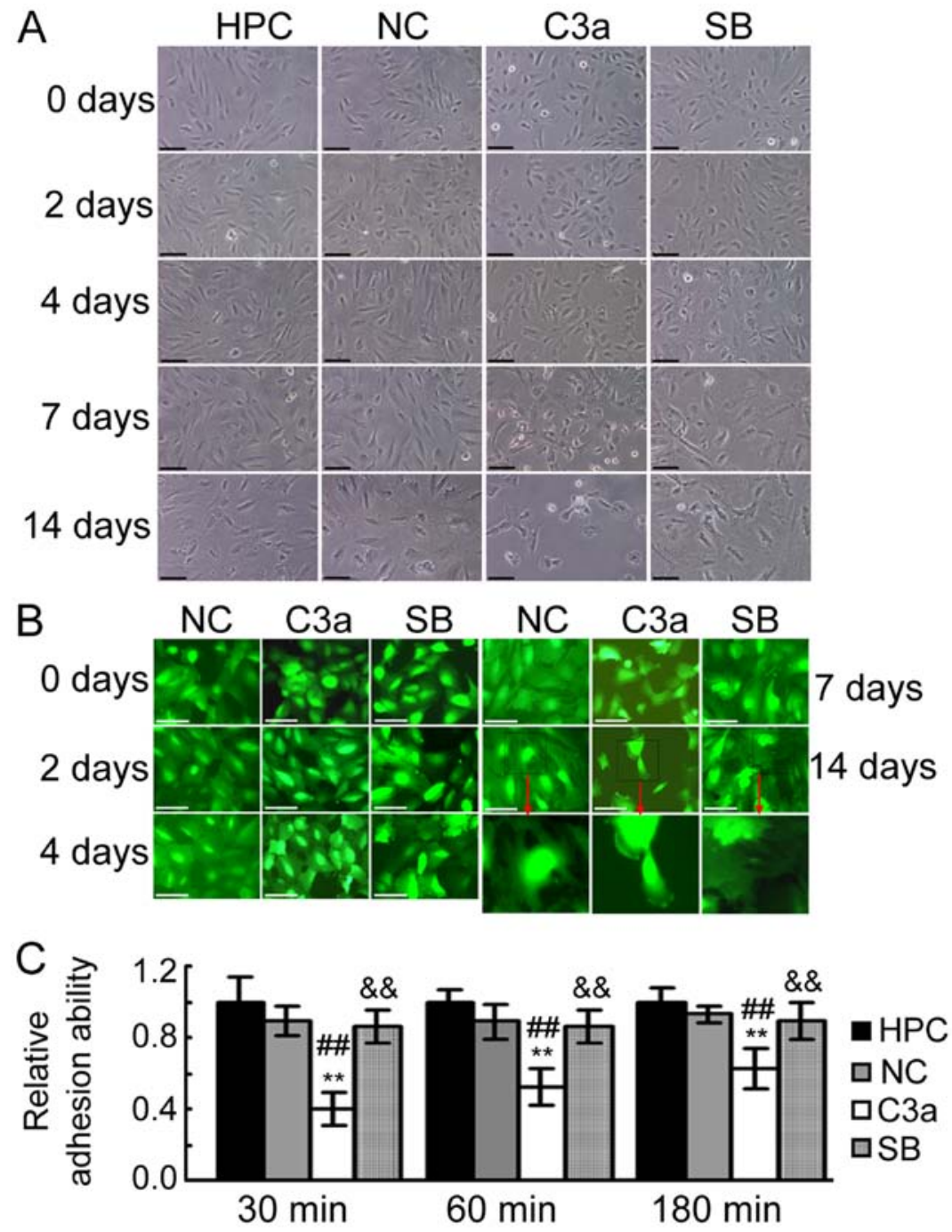

Figure 3. Influence of C3A anaphylatoxin overexpression on the morphology and adhesion ability of HPC cells during maturation. (A) Representative images taken under a phase contrast microscope demonstrating the morphology of HPC, NC, C3a cells and C3a cells treated with $1 \mu$ M of SB290157 cultured during the maturation condition for 0, 2, 4, 7 and 14 days. Scale bar, $100 \mu \mathrm{M}$. (B) Representative images taken with a fluorescence microscope revealing the morphology of NC, C3a and SB cells cultured during the maturation condition for $0,2,4,7$ and 14 days. As normal HPC cells do not exhibit fluorescence, the untransfected HPC cells were not included in the cell morphology observational experiments under fluorescence microscopy. Scale bar, $50 \mu \mathrm{M}$. (C) Results of adhesion analysis. The adhesion ability of HPC, NC, C3a and SB cells was analyzed following culturing in the maturation condition for 6 days. ${ }^{* *} \mathrm{P}<0.01$ vs. the HPC group; ${ }^{\# /} \mathrm{P}<0.01$ vs. the NC group; \&\& $\mathrm{P}<0.01$ vs. the C3a group. C3a, HPC cells overexpressing human C3A anaphylatoxin; HPC, human podocyte cell; NC, HPC cells transfected with negative control vector; SB, C3a cells treated with SB290157.

mechanism of decreased adhesion capacity in HPC-C3a cells, the expression changes of ECM cell adhesion-associated genes were observed. A total of 33 genes that have been reported to be associated with podocyte adhesion were examined. These included 15 genes [collagen I $\alpha 1$ (COL1A1), collagen IV $\alpha 1$ (COL4A1), collagen IV $\alpha 2$ (COL4A2), collagen IV $\alpha 3$ (COL4A3), collagen IV $\alpha 4$ (COL4A4), fibronectin-1 (FN1), laminin $\beta 1$ (LAMB1), laminin $\alpha 1$ (LAMA1), laminin $\gamma 1$ (LAMC1), laminin $\beta 1$ (LAMB1), laminin $\beta 2$ (LAMB2), laminin $\gamma 2$ (LAMC2), laminin $\alpha 3$ (LAMA3), laminin $\beta 3$ (LAMB3) and laminin $\gamma 3$ (LAMC3)] encoding ECM components, 6 genes [integrin $\alpha 1$ (ITGA1), integrin $\alpha 2$ (ITGA2), integrin $\alpha 3$ (ITGA3), integrin $\alpha 5$ (ITGA5), ITGB1 and integrin $\beta 3$ (ITGB3)] encoding integrins and 9 genes [dystroglycan 1 (DAG1), PTK2, integrin linked kinase (ILK), neuropilin 1 (NRP1), talin 1 (TLN1), talin 2 (TLN2), paxillin (PXN), fermitin family member 2
(FERMT2) and VCL] encoding cytoplasmic molecules associated directly with FAs. Additionally, the gene encoding Wilms' tumor 1 (WT1), the molecular marker for podocytes, $\alpha$ smooth muscle actin (ACTA2), the molecular marker for mesenchymal cells and for transforming growth factor $\beta 1$ (TGFB1), an important molecule in regulation of cell proliferation, differentiation, growth, survival, apoptosis, adhesion and migration, were examined. The RT-qPCR results revealed that the expression levels of COL1A1, FN1, LAMA1, LAMB1, LAMC1, ITGA1, ITGA2, ITGB1, PTK2, NRP1, TLN2, FERMT2 and VCL mRNA in HPC-C3a cells were significantly decreased compared with these levels in the untransfected HPC and HPC-NC cells. However, the addition of SB290157 prevented or reduced the decrease in the expression of COL1A1, FN1, LAMA1, LAMB1, LAMC1, ITGA1, ITGA2, ITGB1, PTK2, NRP1, TLN2, FERMT2 and VCL gene (Table II). No significant 


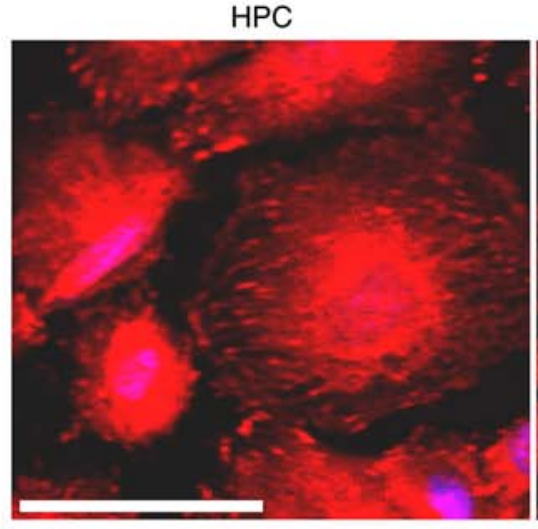

SB

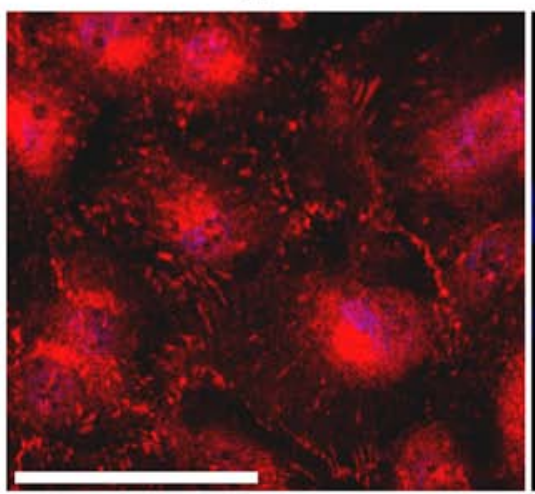

NC

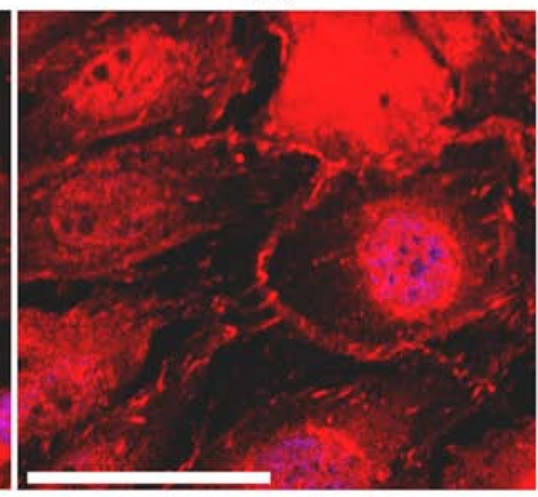

Negative immuno-staining

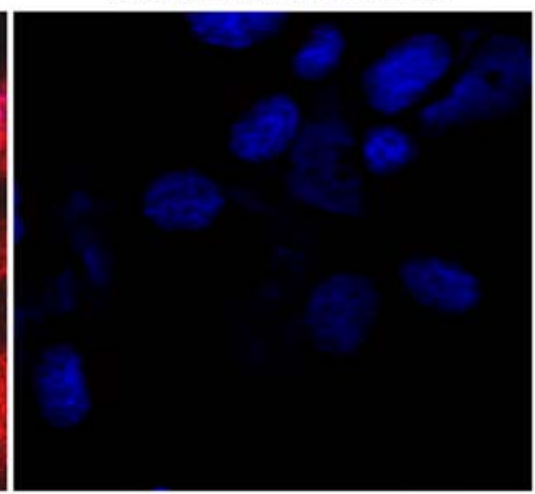

$\mathrm{C} 3 \mathrm{a}$
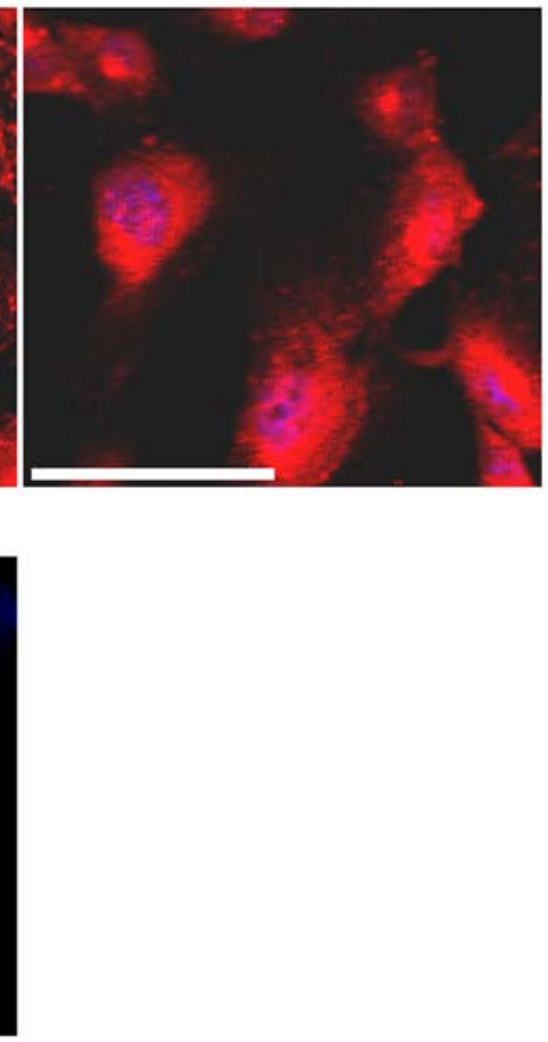

Figure 4. Overexpression of C3a markedly alters the immunostaining pattern of VCL. All cells (HPC, NC, C3a and SB) were grown on glass coverslips. Following culturing in the maturation condition for 6 days, the cells were fixed and stained for VCL. Homologous serum was used instead of anti-VCL antibody as the negative control (negative immuno-staining group). Scale bar, $50 \mu \mathrm{M}$. C3a, human C3A anaphylatoxin; VCL, vinculin; HPC, human podocyte cell line; NC, negative control; SB, SB290157.
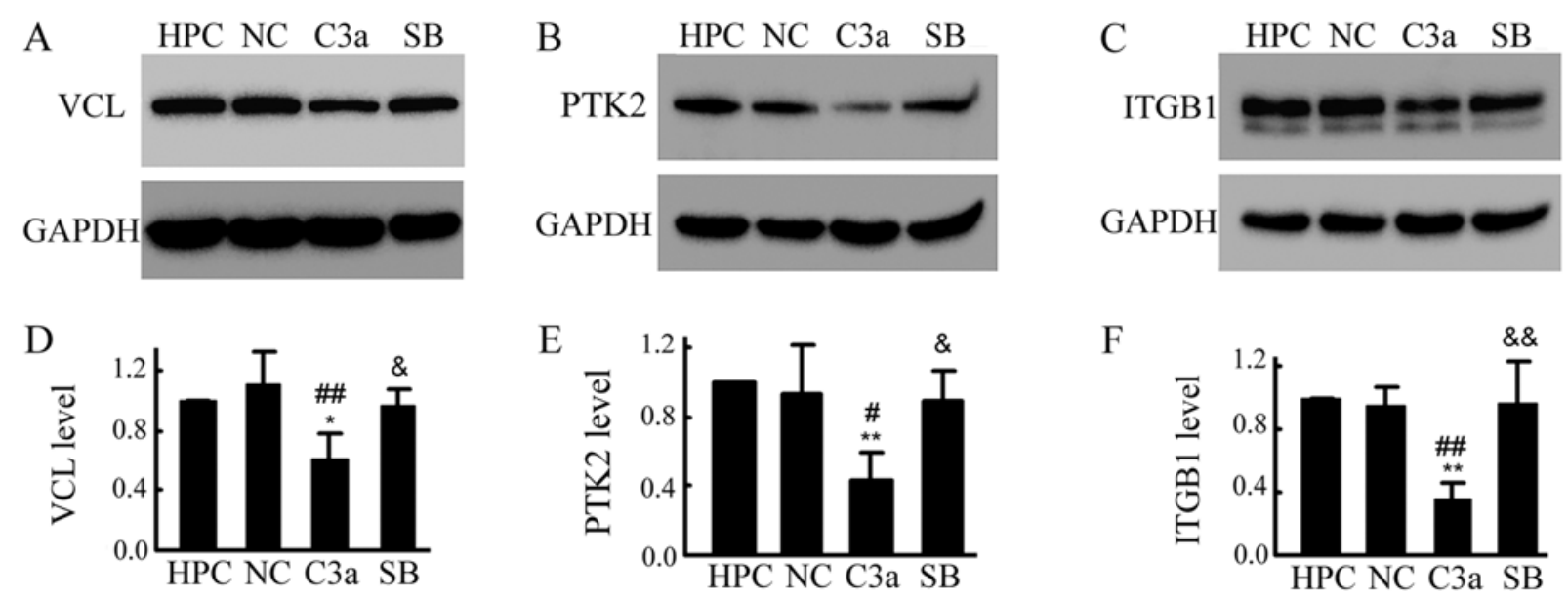

Figure 5. Overexpression of C3a significantly decreased the levels of VCL, PTK2 and ITGB1 in HPC cells. All cells (HPC, NC, C3a and SB) were cultured in the maturation condition for 6 days. Total proteins were extracted and (A-C) western blotting and (D-F) statistical analysis for VCL, PTK2 and ITGB1 was performed. ${ }^{*} \mathrm{P}<0.05,{ }^{* *} \mathrm{P}<0.01$ vs. the HPC group; ${ }^{\#} \mathrm{P}<0.05$, ${ }^{\# \#} \mathrm{P}<0.01$ vs. HPC-NC group; ${ }^{\text {}} \mathrm{P}<0.05$, \&\& $\mathrm{P}<0.01$ vs. the C3a group. C3a, human $\mathrm{C} 3 \mathrm{~A}$ anaphylatoxin; PTK2, protein tyrosine kinase 2; ITGB1, integrin $\beta 1$; HPC, human podocyte cell line; NC, negative control; SB, SB290157; VCL, vinculin.

changes in the expression of COL4A1, COL4A2, COL4A3, COL4A4, LAMA2, LAMB2, LAMC2, LAMA3, LAMB3, LAMC3, ITGA3, ITGA5, ITGB3, DAG1, ILK, PXN, TLN1, PXN, ACTA2, WT1 and TGFB1 were observed between groups.

Additionally, the decreased expression of ITGB1, PTK2 and VCL in HPC-C3a cells was confirmed by western blotting compared with HPC and HPC-NC cells; this decrease was blocked by addition of $1 \mu \mathrm{M}$ SB290157 (Fig. 5).

Given the importance of nephrin in the maintenance of the structure and function of podocytes, the expression of the nephrin gene was examined by RT-qPCR. However, no significant differences were observed between groups (data not shown). 
Table II. Expression levels of cell adhesion-associated genes.

Relative mRNA level

\begin{tabular}{|c|c|c|c|c|}
\hline \multirow[b]{2}{*}{ Gene } & \\
\hline & HPC & HPC-NC & HPC-C3a & $\mathrm{HPC}-\mathrm{C} 3 \mathrm{a}+\mathrm{SB}$ \\
\hline COL1A1 & $1 \pm 0.06$ & $1.19 \pm 0.34$ & $0.28 \pm 0.04^{\mathrm{b}, \mathrm{c}}$ & $0.75 \pm 0.11^{\mathrm{d}}$ \\
\hline COL4A1 & $1 \pm 0.05$ & $1.08 \pm 0.31$ & $1.17 \pm 0.17$ & $1.14 \pm 0.16$ \\
\hline COL4A2 & $1 \pm 0.06$ & $0.95 \pm 0.09$ & $1.04 \pm 0.11$ & $1.00 \pm 0.12$ \\
\hline COL4A3 & $1 \pm 0.10$ & $1.36 \pm 0.39$ & $1.34 \pm 0.43$ & $1.15 \pm 0.15$ \\
\hline COL4A4 & $1 \pm 0.06$ & $1.08 \pm 0.07$ & $1.02 \pm 0.22$ & $0.97 \pm 0.04$ \\
\hline FN1 & $1 \pm 0.13$ & $1.02 \pm 0.28$ & $0.19 \pm 0.05^{\mathrm{b}, \mathrm{c}}$ & $0.62 \pm 0.09^{\mathrm{a,d}}$ \\
\hline LAMA1 & $1 \pm 0.16$ & $0.98 \pm 0.16$ & $0.19 \pm 0.03^{\mathrm{b}, \mathrm{c}}$ & $0.80 \pm 0.12^{\mathrm{e}}$ \\
\hline LAMB1 & $1 \pm 0.07$ & $1.01 \pm 0.08$ & $0.21 \pm 0.07^{b}$ & $0.79 \pm 0.04^{\mathrm{b}, \mathrm{e}}$ \\
\hline LAMC1 & $1 \pm 0.16$ & $1.07 \pm 0.19$ & $0.18 \pm 0.03^{\mathrm{b}, \mathrm{c}}$ & $0.75 \pm 0.04^{\mathrm{a}, \mathrm{e}}$ \\
\hline LAMA2 & $1 \pm 0.24$ & $0.99 \pm 0.12$ & $1.32 \pm 0.40$ & $0.94 \pm 0.19$ \\
\hline LAMB2 & $1 \pm 0.03$ & $0.97 \pm 0.13$ & $1.00 \pm 0.17$ & $0.96 \pm 0.22$ \\
\hline LAMC2 & $1 \pm 0.12$ & $0.93 \pm 0.16$ & $1.00 \pm 0.18$ & $0.92 \pm 0.05$ \\
\hline LAMA3 & $1 \pm 0.05$ & $1.05 \pm 0.20$ & $1.12 \pm 0.15$ & $0.92 \pm 0.05$ \\
\hline LAMB3 & $1 \pm 0.07$ & $1.04 \pm 0.19$ & $1.11 \pm 0.25$ & $1.00 \pm 0.02$ \\
\hline LAMC3 & $1 \pm 0.05$ & $0.94 \pm 0.33$ & $1.22 \pm 0.29$ & $1.05 \pm 0.12$ \\
\hline ITGA1 & $1 \pm 0.22$ & $0.94 \pm 0.15$ & $0.40 \pm 0.04^{\mathrm{b}, \mathrm{c}}$ & $0.92 \pm 0.03^{\mathrm{e}}$ \\
\hline ITGA2 & $1 \pm 0.14$ & $0.86 \pm 0.29$ & $0.26 \pm 0.08^{\mathrm{b}, \mathrm{c}}$ & $0.90 \pm 0.14^{\mathrm{e}}$ \\
\hline ITGA3 & $1 \pm 0.18$ & $0.92 \pm 0.09$ & $0.98 \pm 0.09$ & $0.92 \pm 0.13$ \\
\hline ITGA5 & $1 \pm 0.13$ & $1.07 \pm 0.24$ & $0.98 \pm 0.40$ & $1.06 \pm 0.22$ \\
\hline ITGB1 & $1 \pm 0.14$ & $0.86 \pm 0.29$ & $0.27 \pm 0.07^{\mathrm{b}, \mathrm{c}}$ & $0.80 \pm 0.15^{\mathrm{e}}$ \\
\hline ITGB3 & $1 \pm 0.18$ & $1.05 \pm 0.18$ & $1.11 \pm 0.15$ & $1.09 \pm 0.10$ \\
\hline DAG1 & $1 \pm 0.15$ & $1.05 \pm 0.11$ & $1.08 \pm 0.10$ & $1.04 \pm 0.16$ \\
\hline PTK2 & $1 \pm 0.26$ & $0.85 \pm 0.10$ & $0.38 \pm 0.08^{\mathrm{b}, \mathrm{c}}$ & $0.80 \pm 0.09^{\mathrm{e}}$ \\
\hline ILK & $1 \pm 0.04$ & $0.98 \pm 0.13$ & $1.01 \pm 0.11$ & $0.96 \pm 0.07$ \\
\hline NRP1 & $1 \pm 0.08$ & $1.06 \pm 0.14$ & $0.45 \pm 0.12^{\mathrm{b}, \mathrm{c}}$ & $0.90 \pm 0.19^{\mathrm{e}}$ \\
\hline TLN1 & $1 \pm 0.08$ & $0.93 \pm 0.11$ & $0.98 \pm 0.16$ & $0.92 \pm 0.15$ \\
\hline TLN2 & $1 \pm 0.12$ & $0.92 \pm 0.15$ & $0.48 \pm 0.08^{\mathrm{b}, \mathrm{c}}$ & $0.86 \pm 0.08^{\mathrm{e}}$ \\
\hline PXN & $1 \pm 0.14$ & $1.14 \pm 0.25$ & $1.24 \pm 0.05$ & $0.93 \pm 0.21$ \\
\hline FERMT2 & $1 \pm 0.15$ & $0.94 \pm 0.11$ & $0.55 \pm 0.15^{\mathrm{b}, \mathrm{c}}$ & $0.90 \pm 0.09^{\mathrm{d}}$ \\
\hline VCL & $1 \pm 0.11$ & $1.00 \pm 0.13$ & $0.60 \pm 0.02^{\mathrm{b}, \mathrm{c}}$ & $090 \pm 0.19^{d}$ \\
\hline ACTA2 & $1 \pm 0.10$ & $0.96 \pm 0.19$ & $0.99 \pm 0.12$ & $0.93 \pm 0.18$ \\
\hline WT1 & $1 \pm 0.11$ & $0.90 \pm 0.07$ & $0.97 \pm 0.13$ & $0.91 \pm 0.15$ \\
\hline TGFB1 & $1 \pm 0.11$ & $0.94 \pm 0.22$ & $0.90 \pm 0.13$ & $0.97 \pm 0.19$ \\
\hline
\end{tabular}

${ }^{a} \mathrm{P}<0.05$ and ${ }^{\mathrm{b}} \mathrm{P}<0.01$ vs. the HPC group. ${ }^{\mathrm{C}}<0.01$ vs HPC-NC group. ${ }^{\mathrm{d}} \mathrm{P}<0.05$ and ${ }^{\mathrm{e}} \mathrm{P}<0.01$ vs. the HPC-C 3 a group. Values are presented as mean \pm SEM. HPC, human podocyte cell; NC, negative control; C3a, C3a, human C3A anaphylatoxin; SB, SB290157. COL1A1, collagen I $\alpha 1$; COL4A1, collagen IV $\alpha 1$; COL4A2, collagen IV $\alpha 2$; COL4A3, collagen IV $\alpha 3$; COL4A4, collagen IV $\alpha 4$; C3aR, complement C3a receptor 1; FN1, fibronectin-1; LAMA1, laminin $1 \alpha$; LAMB1, laminin $1 \beta$; LAMC1, laminin 1 $\gamma$; LAMA1, laminin $\alpha 1$; LAMB2; laminin $\beta 2 ;$ LAMC2, laminin $2 \gamma$; LAMA3, laminin $\alpha 3$; LAMB3, laminin $\beta 3$; LAMC3, laminin $3 \gamma$; ITGA1, integrin $\alpha 1$; ITGA2, integrin $\alpha 2$; ITGA3, integrin $\alpha 3$; ITGA5, integrin $\alpha 5$; ITGB1, integrin $\beta 1$; ITGB3, integrin $\beta 3$; DAG1, dystroglycan 1 ; PTK2, protein tyrosine kinase 2; ILK, integrin linked kinase; NRP1, neuropilin 1; TLN1, talin 1; TLN2, talin 2; PXN , paxillin; FERMT2, fermitin family member 2; VCL, vinculin; ACTA2, $\alpha$ smooth muscle actin; WT1, Wilms' tumor 1 ; TGFB1, transforming growth factor $\beta 1$; CPD, carboxypeptidase D; CPM, carboxypeptidase M; CPN1, carboxypeptidase N1; CPN2, carboxypeptidase N2; CPZ, carboxypeptidase Z.

Addition of $\mathrm{C} 3$ a to the medium only partially mimicked the effect of overexpression of C3a in HPC cells. To further examine the effect of $\mathrm{C} 3 \mathrm{aR}$ activation on the maturation of HPC cells, the cells were treated with purified human $\mathrm{C} 3 \mathrm{a}$. Similar to the effect of $\mathrm{C} 3 \mathrm{a}$ overexpression, the expression of FN1, LAMB1, FERMT2, LAMA1 and LAMC1 in HPC cells treated with $\mathrm{C} 3 \mathrm{a}$ for 6 days (adding purified C3a every two days) was significantly decreased compared with the untreated HPC group. The addition of SB290157 prevented the decrease in the expression of FN1, LAMB1, FERMT2, LAMA1 and LAMC1 in HPC cells. However, C3a had no significant effect on the expression of COL1A1, ITGA1, 
A
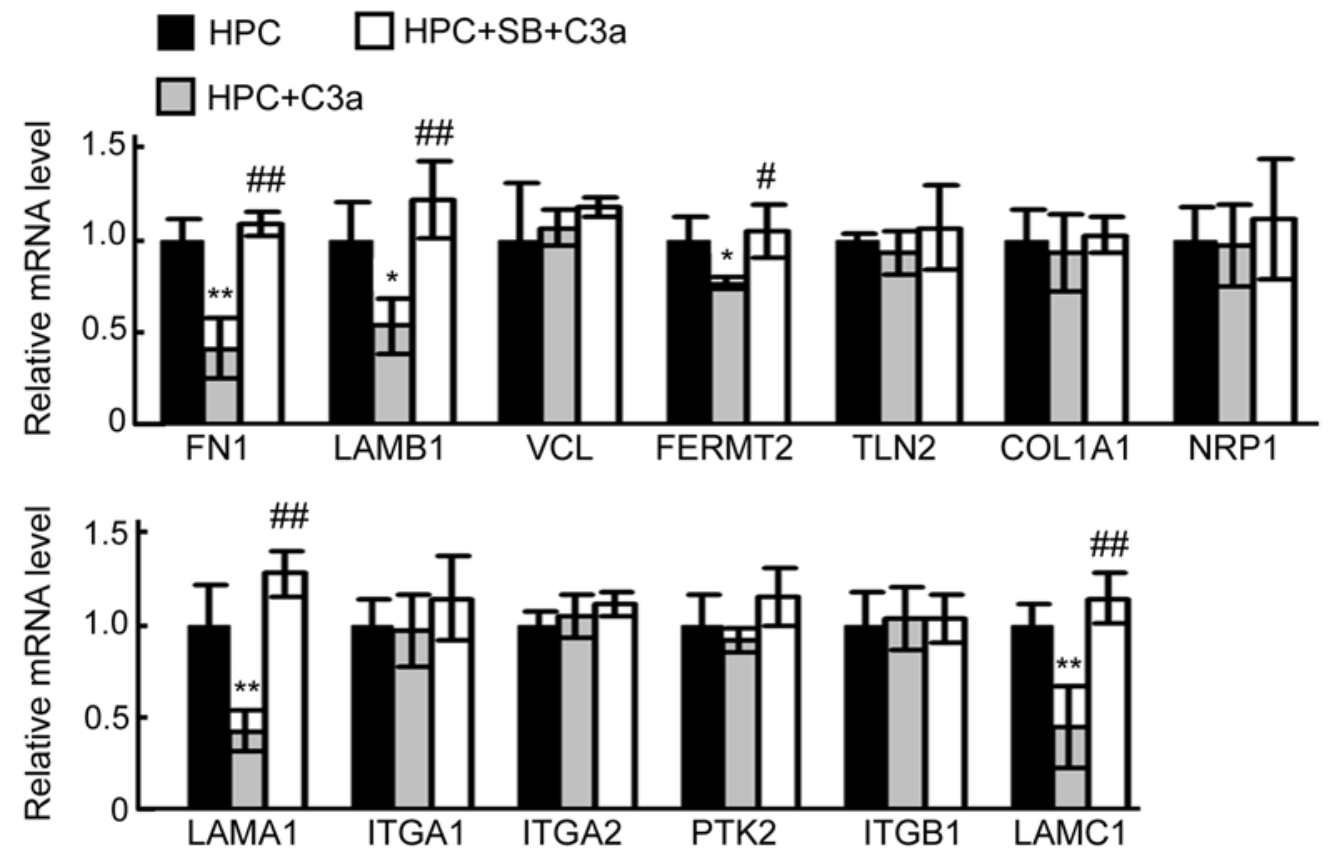

B
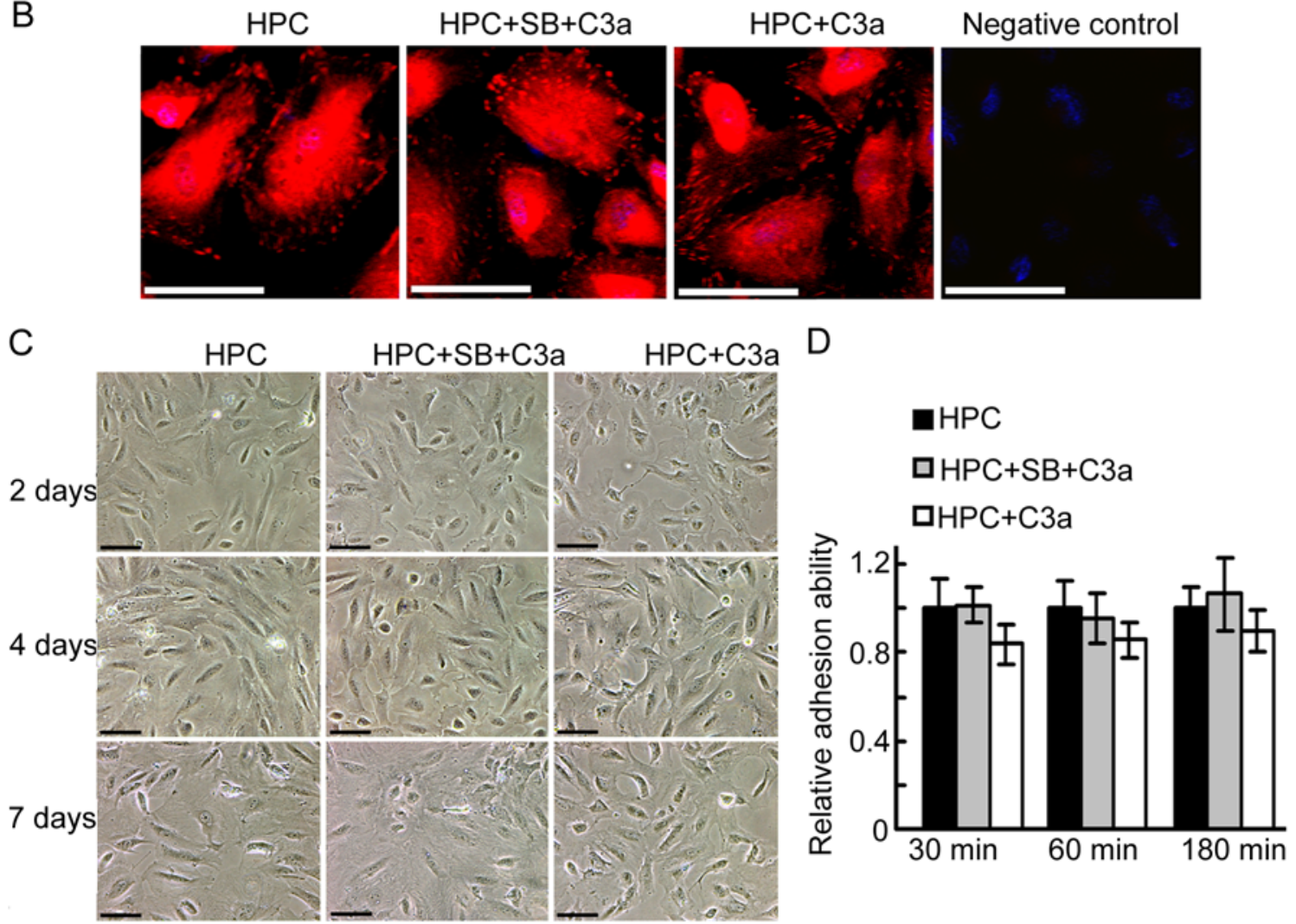

Figure 6. Addition of $\mathrm{C} 3 \mathrm{a}$ to the medium only partially mimics the effect of overexpression of C3a in HPC cells. HPC cells were divided into three groups: $\mathrm{HPC}, \mathrm{HPC}+\mathrm{SB}+\mathrm{C} 3 \mathrm{a}$ and $\mathrm{HPC}+\mathrm{C} 3 \mathrm{a}$. Morphological changes were observed under a phase contrast microscope. (A) Reverse transcription-PCR analysis of the expression of focal adhesion-associated genes. ${ }^{~} \mathrm{P}<0.05,{ }^{* *} \mathrm{P}<0.01$ vs HPC group; ${ }^{*} \mathrm{P}<0.05,{ }^{\# \#} \mathrm{P}<0.01$ vs HPC+C3a group. (B) Immunofluorescence staining for VCL. Scale bar, $50 \mu \mathrm{M}$. (C) Representative images taken under phase contrast microscopy demonstrated cell morphology. Scale bar, $100 \mu \mathrm{M}$. (D) Results of adhesion analysis. COL1A1, collagen I $\alpha 1$; FN1, fibronectin 1; LAMA1, laminin $\alpha 1$; LAMB1, laminin $\beta 1$; LAMC1, laminin $\gamma 1$; ITGA1, integrin $\alpha 1$; ITGA2, integrin $\alpha 2$; ITGB1, integrin $\beta 1$; PTK2, protein tyrosine kinase 2; NRP1, neuropilin 1; TLN2, talin 2; FERMT2, fermitin family member 2; VCL, vinculin; C3a, human C3a anaphylatoxin; HPC, human podocyte cell; SB, SB290157.

ITGA2, ITGB1, PTK2, NRP1, TLN2 or VCL. Additionally, C3a failed to induce obvious change in the distribution of VCL-positive FAs, adhesive capacity or the detachment of cells (Fig. 6).
HPC cells express carboxypeptidases. Given that $\mathrm{C} 3 \mathrm{a}$ is easily inactivated by carboxypeptidases by cleaving the C-terminal arginine in vivo (25-27), we hypothesized that inactivation of C3a may be one of the causes for the different 


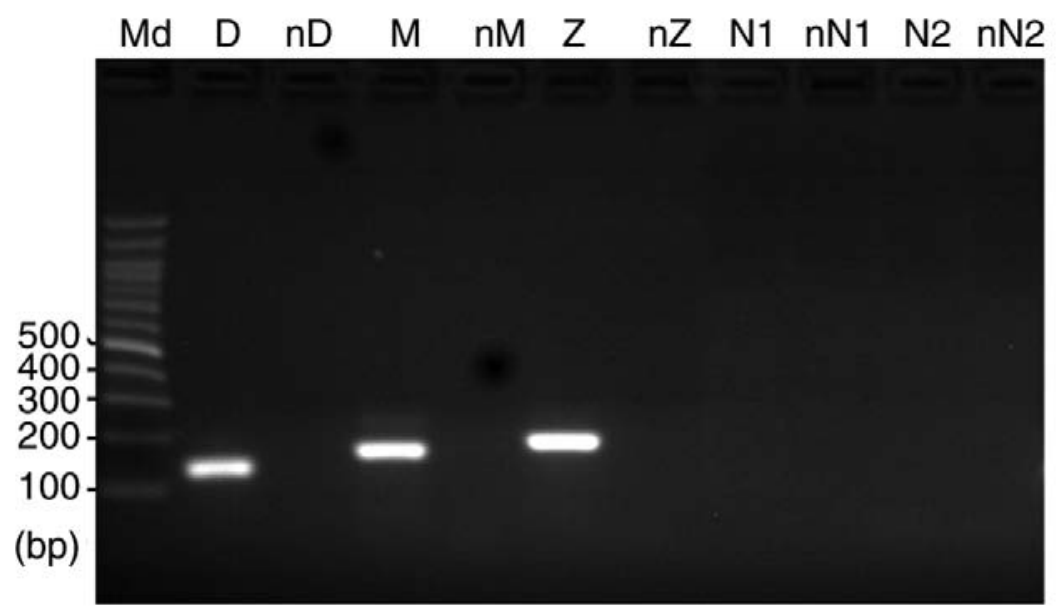

Figure 7. Results of reverse transcription-PCR demonstrated that human podocyte cells express genes for carboxypeptidases Z, M and D. However, cells did not express genes for carboxypeptidases N1 or N2. Md, DNA molecular marker; D, carboxypeptidase D; M, carboxypeptidase M; Z, carboxypeptidase Z; $\mathrm{N} 1$, carboxypeptidase $\mathrm{N} 1$; $\mathrm{N}$, carboxypeptidase $\mathrm{N} 2 ; \mathrm{nD}, \mathrm{nM}, \mathrm{nZ}, \mathrm{nN} 1$ and $\mathrm{nN}$, negative controls for carboxypeptidases $\mathrm{D}, \mathrm{M}, \mathrm{Z}, \mathrm{N} 1$ and $\mathrm{N} 2$, respectively.

effects observed between $\mathrm{C} 3 \mathrm{a}$ overexpression and addition of purified $\mathrm{C} 3 \mathrm{a}$. To investigate this hypothesis, the expression of carboxypeptidases in HPC cells was examined. As presented in Fig. 7, the results of RT-PCR demonstrated that although carboxypeptidases N1 (CPN1) and N2 (CPN2) were not expressed in HPC cells, carboxypeptidases Z (CPZ), $\mathrm{M}(\mathrm{CPM})$ and D (CPD) were indeed expressed in the cells, supporting our hypothesis that the C3a added to the HPC cultured medium may be degraded by the carboxypeptidases produced by the cells.

\section{Discussion}

To the best of our knowledge, the present study is the first to investigate the effect of the $\mathrm{C} 3 \mathrm{a}$ anaphylatoxin receptor $(\mathrm{C} 3 \mathrm{aR})$ activation on the maturation of podocytes by using human podocyte (HPC) cells. Similar to a previous report (21), HPC cells proliferated and exhibited typical cobblestone morphology when cultured in the proliferation condition. Proliferation ceased and the cells gradually differentiated into mature podocytes with enlarged cell bodies and arborized appearance in the maturation condition. Infection of HPC cells with control lentivirus did not induce an obvious change in the cells. However, infection of HPC cells with Lenti-C3a, which increased the levels of secretory $\mathrm{C} 3 \mathrm{a}$ in the cells, induced marked phenotypic changes, including significantly decreased adhesion capacity, increased tendency to contract and to be detached from the surface of tissue culture plates and failure to expand cell bodies and develop arborized appearance.

Proper attachment of cells to the extracellular matrix (ECM) is a basic requirement to build a multicellular organism. It is the basis for adherent cells to survive and function normally. Given the key role of cell adhesion to the ECM in the behavior of cells, including cellular differentiation, expansion, survival, apoptosis and the maintenance of cell morphology $(24,28)$, it was hypothesized that the markedly decreased adhesion capacity of the cells may be the fundamental cause for the different phenotypes observed in the HPC-C3a cells. In accordance with this hypothesis, addition of the C3aR-specific antagonist SB290157 prevented the decrease in cell adhesion capacity, along with the recovery of the ability for the cells to expand their cell bodies and develop into the arborized appearance.

Cells, including podocytes, attach to ECM mainly through the formation of FAs. FAs are large macromolecular assemblies consisting of ECM components, ECM receptors (integrins) and certain cytoplasmic proteins, and serve as the linkages between the ECM and cellular skeleton (29,30). In addition to anchoring cells, FAs function as signal sensors, which inform the cells about the condition of the ECM to influence the cells to alter their behaviors in response to survival, apoptosis, spreading, differentiation and migration (24). To determine whether the decreased adhesion capacity observed in the HPC-C3a cells was associated with the impairment of FAs, the changes in the structure of FAs was examined by immunostaining for VCL. As a core component of FAs, VCL comprises an $\mathrm{N}$-terminal head domain, a proline-rich linker and a C-terminal tail domain. By binding to talin by its head domain (31) and to paxillin, F-actin and phosphatidylinositol- 4,5-bisphosphate by its tail domain $(32,33)$, VCL serves a pivotal role in stabilizing FAs and controls the potency of cell adhesion binding to ECM $(34,35)$. As expected, C3a overexpression markedly altered the distribution of VCL in HPC cells. Additionally, C3aR inhibition with SB290157 blocked this alteration.

To further explore the cause of the decreased adhesion ability in the HPC-C3a cells, the changes in the expression of FA structure- and function-associated genes was examined. Overexpression of $\mathrm{C} 3 \mathrm{a}$ significantly reduced the expression level of FAs-associated genes, including the genes encoding for LAMA1, LAMB1, LAMC1, FN1, COL1A1, ITGA1, ITGB1, ITGA2, VCL, TLN2, PTK2, NRP1 and FERMT2. LAMA1, LAMB1 and LAMC1 are the three chains of laminin 1. Laminin, collagen and fibronectin are well-known components of the ECM. By interacting with their receptors, ECM components provide mechanical support for cells and have an important role in regulating cell shape and function. For instance, laminin 1 has been reported to serve an important role in orchestrating the development and differentiation of neural cells including extension, migration, survival and 
neurite outgrowth (36-38). Additionally, similar roles have been demonstrated in other ECM components (39). Laminin 1, collagen 1 and fibronectin 1 exert their cellular regulatory roles by interacting with integrins, including $\alpha 1 \beta 1, \alpha 2 \beta 1$ and $\alpha 3 \beta 1$. By binding to their ECM ligands by their extracellular 'lobster claws' domain and interacting with the cytoskeleton system via their cytoplasmic parts, integrins bridge the ECM and cytoskeleton, and are therefore the structural center of the FAs $(40,41)$. Additionally, integrins serve a key role in signal transduction associated with cell growth, division, survival, differentiation and apoptosis (40). Integrins are obligate heterodimers and each integrin has two subunits: $\alpha$ and $\beta$. Mammals exhibit $24 \alpha$ and $9 \beta$ integrins. Among them, integrins $\alpha 1, \alpha 2$ and $\beta 1$ have been reported to be expressed by podocytes and $\alpha 1 \beta 1$, $\alpha 2 \beta 1$ and $\alpha 3 \beta 1$ have been well documented to serve important role in the normal attachment of podocytes to the glomerular basement membrane (42). Genetic deficit or decreased expression of these integrins have been demonstrated to be implicated in abnormal renal development (43), decreased adhesion capacity of glomerular podocytes, podocyte damage $(44,45)$ and renal dysfunction $(46,47)$. VCL, TLN2, PTK2, NRP1 and FERMT2 are the major cytoplasmic components associated with FAs. Either by connecting integrins to cytoskeleton or by mediating signal transduction, these proteins exert their roles in cell adhesion and adhesion-associated cellular function (48-51). Thus, the significantly decreased expression of FA-associated genes explained the decreased adhesion ability of HPC-C3a cells observed in the current study.

As an important component of the slit diaphragm, nephrin serves a key role in podocyte-associated nephropathy. However, the current study did not observe significant change in the expression of nephrin by $\mathrm{C} 3 \mathrm{a}$ overexpression in an RT-qPCR assay.

The present study observed that the effect of C3a overexpression on the phenotype of HPC cells was not completely mimicked by direct addition of $\mathrm{C} 3 \mathrm{a}$ to the cell culture medium. In vivo, $\mathrm{C} 3 \mathrm{a}$ is easily inactivated by carboxypeptidases, which catalyze the removal of the $\mathrm{C}$-terminal arginine of $\mathrm{C} 3 \mathrm{a}$ (25). There are various carboxypeptidases. Among them, $\mathrm{CPN}$ is produced mainly by the liver, circulates in the plasma and contributes to the inactivation of anaphylatoxins including C3a, C4a and C5a (26). Furthermore, CPM, CPD and CPZ have been reported to be able to remove the $\mathrm{C}$-terminal arginine of peptides (27). Moreover, they were hypothesized to function outside the cell and function normally at neutral $\mathrm{pH}$ (27). To investigate the cause for the different effects between the overexpression of $\mathrm{C} 3 \mathrm{a}$ and the direct addition of $\mathrm{C} 3 \mathrm{a}$ on HPC cells, the expression of CPN (encoded by the genes CPN1 and CPN2), CPM, CPD and CPZ genes in HPC cells were examined. HPC cells expressed CPM, CPD and CPZ genes; however, the cells did not express CPN. Therefore, it seems reasonable to hypothesize that directly added C3a may be inactivated by HPC cell derived carboxypeptidases, including CPM, CPD and CPZ, and thus can only activate C3aR in HPC cells temporarily. This is quite different compared with $\mathrm{C} 3 \mathrm{a}$ overexpression in the cells, in which $\mathrm{C} 3 \mathrm{a}$ is produced continuously and, therefore, may induce sustained receptor activation.

The present studies had certain limitations. Firstly, as the current study was an in vitro study, in vivo investigations are required. Secondly, while the present study only observed the influence of $\mathrm{C} 3 \mathrm{a}$ overexpression in the morphological maturation of podocytes, the pathways through which the overexpressed $\mathrm{C} 3 \mathrm{a}$ may exert its role remain to be clarified. Lastly, as all the commercial kits detected both $\mathrm{C} 3 \mathrm{a}$ and $\mathrm{C} 3 \mathrm{a}$ desArg (the inactivated form of $\mathrm{C} 3 \mathrm{a}$ ), it could not be confirmed whether the added $\mathrm{C} 3 \mathrm{a}$ was directly inactivated by podocyte-derived carboxypeptidases.

In summary, through the overexpression of the secretory C3a in HPC cells, the current study investigated the effect of sustained activation of C3aR on the maturation of HPC cells. The results demonstrated that sustained activation of $\mathrm{C} 3 \mathrm{aR}$ impaired the morphological maturation of HPC cells. This effect may be associated with the decreased adhesion ability of the cells to the ECM and caused by the decreased expression of FA-associated genes. These results revealed novel function of $\mathrm{C} 3 \mathrm{aR}$ signaling in podocytes and provided novel insight into the mechanism underlying the regulation of podocyte morphology development. Presently, it is not clear whether the overactivation of $\mathrm{C} 3 \mathrm{aR}$ induces impairment of podocyte maturation in vivo. However, chronically increased complement activation has been reported in renal diseases (52-56), which may indicate increased $\mathrm{C} 3 \mathrm{a}$ and the chronic activation of $\mathrm{C} 3 \mathrm{aR}$ in renal cells, including podocytes and renal progenitor cells [for instance, parietal epithelial cells (57-61)]. The possible pathological role of excessive C3aR signaling in the dysregulation of podocyte architecture and podocyte regeneration requires further research.

\section{Acknowledgements}

Not applicable.

\section{Funding}

The current study was supported by the Science Foundation of Taizhou City (grant no. 1801ky02).

\section{Availability of data and materials}

The datasets used and/or analyzed during the current study are available from the corresponding author on reasonable request.

\section{Authors' contributions}

JMZ designed the current research, performed experiments and drafted and revised the manuscript. SSW and XT performed the experiments, analyzed data and drafted and revised the manuscript. DJC participated in data analysis and revised the manuscript. All authors read and approved the final manuscript and agree to be accountable for all aspects of the research in ensuring that the accuracy or integrity of any part of the work are appropriately investigated and resolved.

\section{Ethics approval and consent to participate}

Not applicable.

\section{Patient consent for publication}

Not applicable. 


\section{Competing interests}

The authors declare that they have no competing interests.

\section{References}

1. Hawksworth OA, Coulthard LG, Mantovani S and Woodruff TM: Complement in stem cells and development. Semin Immunol 37: 74-84, 2018

2. Hawksworth OA, Coulthard LG and Woodruff TM: Complement in the fundamental processes of the cell. Mol Immunol 84: 17-25, 2017.

3. Kwan WH, van der Touw W, Paz-Artal E, Li MO and Heeger PS: Signaling through $\mathrm{C} 5 \mathrm{a}$ receptor and $\mathrm{C} 3$ a receptor diminishes function of murine natural regulatory T cells. J Exp Med 210: 257-268, 2013.

4. Peng Q, Li K, Sacks SH and Zhou W: The role of anaphylatoxins $\mathrm{C} 3 \mathrm{a}$ and $\mathrm{C} 5 \mathrm{a}$ in regulating innate and adaptive immune responses. Inflamm Allergy Drug Targets 8: 236-246, 2009.

5. Sacks SH: Complement fragments $\mathrm{C} 3 \mathrm{a}$ and $\mathrm{C} 5 \mathrm{a}$ : The salt and pepper of the immune response. Eur J Immunol 40: 668-670, 2010.

6. Lim J, Iyer A, Suen JY, Seow V, Reid RC, Brown L and Fairlie DP: $\mathrm{C} 5 \mathrm{aR}$ and $\mathrm{C} 3 \mathrm{aR}$ antagonists each inhibit diet-induced obesity, metabolic dysfunction, and adipocyte and macrophage signaling. FASEB J 27: 822-831, 2013.

7. Ohinata $\mathrm{K}$ and Yoshikawa M: Food intake regulation by central complement system. Adv Exp Med Biol 632: 35-46, 2008.

8. Bénard M, Raoult E, Vaudry D, Leprince J, Falluel-Morel A, Gonzalez BJ, Galas L, Vaudry H and Fontaine M: Role of complement anaphylatoxin receptors $(\mathrm{C} 3 \mathrm{aR}, \mathrm{C} 5 \mathrm{aR})$ in the development of the rat cerebellum. Mol Immunol 45: 3767-3774, 2008

9. Broders-Bondon F, Paul-Gilloteaux P, Gazquez E, Heysch J, Piel M, Mayor R, Lambris JD and Dufour S: Control of the collective migration of enteric neural crest cells by the Complement anaphylatoxin C3a and N-cadherin. Dev Biol 414 85-99, 2016.

10. Xu XH, Peng HS, Sun MQ, Hu M, Zhang R, Wang WH, He XY and Xiao XR: C-terminal peptide of anaphylatoxin C3a enhances hepatic function after steatotic liver transplantation: A study in a rat model. Transplant Proc 42: 737-740, 2010

11. Davoust N, Jones J, Stahel PF, Ames RS and Barnum SR Receptor for the C3a anaphylatoxin is expressed by neurons and glial cells. Glia 26: 201-211, 1999.

12. Rahpeymai Y, Hietala MA, Wilhelmsson U, Fotheringham A, Davies I, Nilsson AK, Zwirner J, Wetsel RA, Gerard C, Pekny M, et al: Complement: A novel factor in basal and ischemia-induced neurogenesis. EMBO J 25: 1364-1374, 2006.

13. Shinjyo N, de Pablo Y, Pekny M and Pekna M: Complement Peptide C3a Promotes Astrocyte Survival in Response to Ischemic Stress. Mol Neurobiol 53: 3076-3087, 2016.

14. Stokowska A, Atkins AL,Morán J,Pekny T,Bulmer L,Pascoe MC, Barnum SR, Wetsel RA, Nilsson JA, Dragunow M et al: Complement peptide C3a stimulates neural plasticity after experimental brain ischaemia. Brain 140: 353-369, 2017.

15. Shinjyo N, Ståhlberg A, Dragunow M, Pekny M and Pekna M: Complement-derived anaphylatoxin $\mathrm{C} 3$ a regulates in vitro differentiation and migration of neural progenitor cells. Stem Cells 27 2824-2832, 2009

16. Schlondorff J: How many Achilles' heels does a podocyte have? An update on podocyte biology. Nephrol Dial Transplant 30 1091-1097, 2015

17. Nagata M: Podocyte injury and its consequences. Kidney Int 89: 1221-1230, 2016.

18. Reiser J and Sever S: Podocyte biology and pathogenesis of kidney disease. Annu Rev Med 64: 357-366, 2013.

19. Li X, Ding F, Zhang X, Li B and Ding J: The Expression Profile of Complement Components in Podocytes. Int J Mol Sci 17: 471, 2016.

20. Locatelli M, Buelli S, Pezzotta A, Corna D, Perico L, Tomasoni S, Rottoli D, Rizzo P, Conti D, Thurman JM, et al: Shiga toxin promotes podocyte injury in experimental hemolytic uremic syndrome via activation of the alternative pathway of complement. J Am Soc Nephrol 25: 1786-1798, 2014.

21. Saleem MA, O'Hare MJ, Reiser J, Coward RJ, Inward CD, Farren T, Xing CY, Ni L, Mathieson PW and Mundel P: A conditionally immortalized human podocyte cell line demonstrating nephrin and podocin expression. J Am Soc Nephrol 13: 630-638, 2002 .
22. Boos L, Campbell IL, Ames R, Wetsel RA and Barnum SR: Deletion of the complement anaphylatoxin $\mathrm{C} 3 \mathrm{a}$ receptor attenuates, whereas ectopic expression of $\mathrm{C} 3 \mathrm{a}$ in the brain exacerbates, experimental autoimmune encephalomyelitis. J Immunol 173: 4708-4714, 2004.

23. Livak KJ and Schmittgen TD: Analysis of relative gene expression data using real-time quantitative PCR and the $2(-\Delta \Delta \mathrm{C}(\mathrm{T}))$ Method. Methods 25: 402-408, 2001.

24. Riveline D, Zamir E, Balaban NQ, Schwarz US, Ishizaki T, Narumiya S, Kam Z, Geiger B and Bershadsky AD: Focal contacts as mechanosensors: Externally applied local mechanical force induces growth of focal contacts by an mDial-dependent and ROCK-independent mechanism. J Cell Biol 153: 1175-1186, 2001.

25. Yadav P, Goyal VD, Gaur NK, Kumar A, Gokhale SM, Jamdar SN and Makde RD: Carboxypeptidase in prolyl oligopeptidase family: Unique enzyme activation and substrate-screening mechanisms. J Biol Chem 294: 89-100, 2019.

26. Matthews KW, Mueller-Ortiz SL and Wetsel RA: Carboxypeptidase N: A pleiotropic regulator of inflammation. Mol Immunol 40: 785-793, 2004.

27. Reznik SE and Fricker LD: Carboxypeptidases from A to Z: Implications in embryonic development and Wnt binding. Cell Mol Life Sci 58: 1790-1804, 2001.

28. Horton ER, Byron A, Askari JA, Ng DHJ, Millon-Frémillon A, Robertson J, Koper EJ, Paul NR, Warwood S, Knight D, et al: Definition of a consensus integrin adhesome and its dynamics during adhesion complex assembly and disassembly. Nat Cell Biol 17: 1577-1587, 2015.

29. Zaidel-Bar R, Cohen M, Addadi L and Geiger B: Hierarchical assembly of cell-matrix adhesion complexes. Biochem Soc Trans 32: 416-420, 2004.

30. Zamir E and Geiger B: Molecular complexity and dynamics of cell-matrix adhesions. J Cell Sci 114: 3583-3590, 2001.

31. Peng X, Maiers JL, Choudhury D, Craig SW and DeMali KA: $\alpha$-catenin uses a novel mechanism to activate vinculin. J Biol Chem 287: 7728-7737, 2012.

32. Grashoff C, Hoffman BD, Brenner MD, Zhou R, Parsons M, Yang MT, McLean MA, Sligar SG, Chen CS, Ha T, et al: Measuring mechanical tension across vinculin reveals regulation of focal adhesion dynamics. Nature 466: 263-266, 2010.

33. Hemmings L, Rees DJ, Ohanian V, Bolton SJ, Gilmore AP, Patel B, Priddle H, Trevithick JE, Hynes RO and Critchley DR: Talin contains three actin-binding sites each of which is adjacent to a vinculin-binding site. J Cell Sci 109: 2715-2726, 1996.

34. Goldmann WH: Role of vinculin in cellular mechanotransduction. Cell Biol Int 40: 241-256, 2016.

35. Izard T and Brown DT: Mechanisms and functions of vinculin interactions with phospholipids at cell adhesion sites. J Biol Chem 291: 2548-2555, 2016.

36. Desban N, Lissitzky JC, Rousselle P and Duband JL: alphalbeta1-integrin engagement to distinct laminin-1 domains orchestrates spreading, migration and survival of neural crest cells through independent signaling pathways. J Cell Sci 119: 3206-3218, 2006

37. Mruthyunjaya S, Parveen D, Shah RD, Manchanda R, Godbole R, Vasudevan $M$ and Shastry P: Gene expression analysis of laminin-1-induced neurite outgrowth in human mesenchymal stem cells derived from bone marrow. J Biomed Mater Res A 103: 746-761, 2015.

38. Yamada M and Sekiguchi K: Molecular Basis of Laminin-Integrin Interactions. Curr Top Membr 76: 197-229, 2015.

39. Bachman H, Nicosia J, Dysart M and Barker TH: Utilizing Fibronectin Integrin-Binding Specificity to Control Cellular Responses. Adv Wound Care (New Rochelle) 4: 501-511, 2015.

40. IwamotoDV and CalderwoodDA: Regulation of integrin-mediated adhesions. Curr Opin Cell Biol 36: 41-47, 2015.

41. Li Z, Lee H and Zhu C: Molecular mechanisms of mechanotransduction in integrin-mediated cell-matrix adhesion. Exp Cell Res 349: 85-94, 2016.

42. Sachs N and Sonnenberg A: Cell-matrix adhesion of podocytes in physiology and disease. Nat Rev Nephrol 9: 200-210, 2013.

43. Kanasaki K, Kanda Y,Palmsten K, Tanjore H, Lee SB, Lebleu VS, Gattone VH Jr and Kalluri R: Integrin beta1-mediated matrix assembly and signaling are critical for the normal development and function of the kidney glomerulus. Dev Biol 313: 584-593, 2008.

44. Dessapt C, Baradez MO, Hayward A, Dei Cas A, Thomas SM, Viberti G and Gnudi L: Mechanical forces and TGFbeta1 reduce podocyte adhesion through alpha3betal integrin downregulation. Nephrol Dial Transplant 24: 2645-2655, 2009. 
45. He P, Liu D, Zhang B, Zhou G, Su X, Wang Y, Li D, Yang X, Hepatitis B and Virus X: Hepatitis B Virus X Protein Reduces Podocyte Adhesion via Downregulation of $\alpha 3 \beta 1$ Integrin. Cell Physiol Biochem 41: 689-700, 2017.

46. Borza CM, Su Y, Chen X, Yu L, Mont S, Chetyrkin S, Voziyan P, Hudson BG, Billings PC, Jo H, et al: Inhibition of integrin $\alpha 2 \beta 1$ ameliorates glomerular injury. J Am Soc Nephrol 23: 1027-1038, 2012.

47. Pozzi A, Jarad G, Moeckel GW, Coffa S, Zhang X, Gewin L, Eremina V, Hudson BG, Borza DB, Harris RC, et al: Betal integrin expression by podocytes is required to maintain glomerular structural integrity. Dev Biol 316: 288-301, 2008.

48. Chen C, Li R, Ross RS and Manso AM: Integrins and integrin-related proteins in cardiac fibrosis. J Mol Cell Cardiol 93: 162-174, 2016.

49. Li SY, Mruk DD and Cheng CY: Focal adhesion kinase is a regulator of F-actin dynamics: New insights from studies in the testis. Spermatogenesis 3: e25385, 2013.

50. Mierke CT: The role of focal adhesion kinase in the regulation of cellular mechanical properties. Phys Biol 10: 065005, 2013.

51. Yasuda-Yamahara $M$, Rogg $M$, Frimmel J, Trachte $P$, Helmstaedter M, Schroder P, Schiffer M, Schell C and Huber TB: FERMT2 links cortical actin structures, plasma membrane tension and focal adhesion function to stabilize podocyte morphology. Matrix Biol 68-69: 263-279, 2018.

52. Heeringa SF and Cohen CD: Kidney diseases caused by complement dysregulation: Acquired, inherited, and still more to come. Clin Dev Immunol 2012: 695131, 2012.

53. Jalal D, Renner B, Laskowski J, Stites E, Cooper J, Valente K, You Z, Perrenoud L, Le Quintrec M, Muhamed I, et al: Endothelial microparticles and systemic complement activation in patients with chronic kidney disease. J Am Heart Assoc 7 e007818, 2018
54. Lesher AM and Song WC: Review: Complement and its regulatory proteins in kidney diseases. Nephrology (Carlton) 15: 663-675, 2010.

55. Mizuno M, Suzuki Y and Ito Y: Complement regulation and kidney diseases: Recent knowledge of the double-edged roles of complement activation in nephrology. Clin Exp Nephrol 22: 3-14, 2018.

56. Salant DJ: Introduction: Complement-mediated kidney diseases. Semin Nephrol 33: 477-478, 2013.

57. Eng DG, Sunseri MW, Kaverina NV, Roeder SS, Pippin JW and Shankland SJ: Glomerular parietal epithelial cells contribute to adult podocyte regeneration in experimental focal segmental glomerulosclerosis. Kidney Int 88: 999-1012, 2015.

58. Shankland SJ, Freedman BS and Pippin JW: Can podocytes be regenerated in adults? Curr Opin Nephrol Hypertens 26 154-164, 2017.

59. Bao L, Osawe I, Haas M and Quigg RJ: Signaling through up-regulated C3a receptor is key to the development of experimental lupus nephritis. J Immunol 175: 1947-1955, 2005.

60. Braun MC, Reins RY, Li TB, Hollmann TJ, Dutta R, Rick WA Teng $\mathrm{BB}$ and $\mathrm{Ke} \mathrm{B}$ : Renal expression of the $\mathrm{C} 3 \mathrm{a}$ receptor and functional responses of primary human proximal tubular epithelial cells. J Immunol 173: 4190-4196, 2004.

61. Horton ER, Byron A, Askari JA, Ng DHJ, Millon-Frémillon A, Robertson J, Koper EJ, Paul NR, Warwood S, Knight D, et al: Definition of a consensus integrin adhesome and its dynamics during adhesion complex assembly and disassembly. Nat Cell Biol 17: 1577-1587, 2015. International (CC BY-NC-ND 4.0) License. 